For citation: Ekonomika regiona [Economy of Region]. - 2016. — Vol. 12, Issue 4. - pp. 1178-1193

doi 10.17059/2016-4-19

JEL Classifications: F1, F23, J38

M. M. Ali ${ }^{\text {a) }}$, A. Medhekar ${ }^{\text {b) }}$

a) Daffodil International University (Dhaka, Bangladesh; e-mail: pipulbd@gmail.com)

b) Central Queensland University (Rockhampton, Australia)

\title{
A POOR COUNTRY CLOTHING THE RICH COUNTRIES: CASE OF GARMENT TRADE IN BANGLADESH
}

The ready-made garment industry of Bangladesh is one of the largest formal manufacturing sectors. It has played a key role in the country's process of industrialisation, empowerment of women, export oriented development and growth. Workers from poor socio-economic backgrounds are working in the garment industry. Their health, safety and working conditions are very poor and not protected. There is a lack of regular inspection and compliance with local law in buildings and factories. This led to the collapse of the eight story Rana Plaza building in the capital Dhaka on the 24th of April 2013, "killing 1,100 workers and 2,500 injured". The main aim of the study is to assess the impact of Rana Plaza Tragedy, where RMG workers make garments for multinational brands of Australia, Europe and USA, and the advantage which took these companies of the absence of labour laws, workplace health and safety standards, building standards, long working hours and low wages in Bangladesh. The study used both primary and secondary data including related case studies. The practical application of the study is to develop formal ethical, labour-law, health and safety standards for a factory worker; construction; institutions and courts for monitoring the supplier's behaviour onshore and large multinational firms offshore. The study recommends to protect the rights of women workers who are sowing garments for the fashion conscious consumers from the developed countries. Future research will explore inclusive growth for workers and how to stimulate inclusive sustainable business for export led garment industry.

Keywords: Bangladesh, Rana Plaza, garment industry, women labour, textile, trade, multinational, brands, wage, safety, sustainable business

\section{Introduction}

The Bangladesh ready-made Garment industry is one of the largest manufacturing export oriented sector since mid-eighties, generating seventy percent of export earnings for the Bangladesh economy and providing employment to millions of workers. Garment sector has played a key role in the country's process of women's empowerment, globalisation [1], economic development, industrialisation, and is an export-led model for economic growth [2] for developing countries. The sector has about 4 million garment workers employed, and of which $80 \%$ are women, from poor rural households [3]. [4, c. 70] argued that "the ready-made garment industry is under the threat of continuous unrest in Bangladesh". Workers in this industry are not happy with their wages and the working environment and conditions of the factories. Plan-Do-Check-Act process in the RMG

\footnotetext{
1 (c) Ali M.M., Medhekar A. Text. 2016.

${ }^{2}$ Forbes Asia (2014). A Guide to Rana Plaza Tragedy and its implications in Bangladesh. Retrieved from: http://www.forbes. $\mathrm{com} /$ sites/alyssaayres/2014/04/24/a-guide-to-the-rana-plazatragedy-and-its-implications-in-bangladesh/ (date of access: Viewed 24-4-2014).
}

sector is required for continuous improvement to attain competitive advantage. The long run sustainability and value adding to the readymade garment (RMG) sector can be achieved through regional cooperation such as BIMSTEC and also public-private-foreign collaboration.

The issue of labour unrest is not only related to worker's wages, but also to other non-wage issues such as: high overtime working hours, lack of leisure and holidays, lack of day child-care, canteen and other facilities like restroom and unsatisfactory overall working environment, especially for women. However, China is starting to lose its attractiveness in this realm [5]. With Bangladesh having developed a strong position among European and US buyers, many companies are already eager to evaluate the future potential. The lure of competitive prices, available capacities, and supplier capabilities is being cautiously weighed against a prevailing insecurity created by the challenges inherent in Bangladesh's ready-made garments (RMG) market. Various foreign buyers of readymade garments (RMG) are exploiting Bangladeshi suppliers by first buying products from them and later terming them as "non-compliant".5 As a result, Bangladeshi RMG entrepreneurs face the problem 
Export performance for the period of 2014-15 to 2015-16 (July to February)

\begin{tabular}{|l|c|c|c|c|c|c|c|}
\hline $\begin{array}{c}\text { Products } \\
\text { Value in } \\
\text { Million US \$ }\end{array}$ & $\begin{array}{c}\text { Export } \\
\text { Performan- } \\
\text { ce for } \\
\mathbf{2 0 1 4 - 2 0 1 5} \\
\text { (July-June) }\end{array}$ & $\begin{array}{c}\text { Export } \\
\text { Target for } \\
\mathbf{2 0 1 5 - 2 0 1 6}\end{array}$ & $\begin{array}{c}\text { Target for } \\
\text { July-Feb. } \\
\mathbf{2 0 1 5 - 2 0 1 6}\end{array}$ & $\begin{array}{c}\text { Export } \\
\text { Performa- } \\
\text { nce for } \\
\text { July-Feb. } \\
\mathbf{2 0 1 5 - 2 0 1 6}\end{array}$ & $\begin{array}{c}\text { Change } \\
\text { of Export } \\
\text { Performance } \\
\text { (\%) Over } \\
\text { Export } \\
\text { Target }\end{array}$ & $\begin{array}{c}\text { Export } \\
\text { Performa- } \\
\text { nce for } \\
\text { July-Feb. } \\
\mathbf{2 0 1 4 - 2 0 1 5}\end{array}$ & $\begin{array}{c}\text { Change } \\
\text { of Export } \\
\text { Performa-nce } \\
\text { (\%) July-Feb. } \\
\mathbf{2 0 1 4 - 2 0 1 5} \\
\text { to July-Feb. } \\
\mathbf{2 0 1 5 - 2 0 1 6}\end{array}$ \\
\hline Knitwear & 12426.79 & 13266.21 & 8559.68 & 8643.41 & 0.98 & 8138.30 & 6.21 \\
\hline $\begin{array}{l}\text { Woven } \\
\text { Garments }\end{array}$ & 13064.61 & 14105.42 & 9101.15 & 9484.22 & 4.21 & 8413.19 & 12.73 \\
\hline Home Textile & 804.34 & 850.00 & 548.44 & 484.81 & -11.60 & 517.18 & -6.26 \\
\hline $\begin{array}{l}\text { i) Bed, } \\
\text { Kitchen toilet }\end{array}$ & 523.65 & 550.00 & 354.87 & 308.97 & -12.93 & 348.76 & -11.41 \\
\hline lines & 280.69 & 300.00 & 193.57 & 175.84 & -9.16 & 168.42 & 4.41 \\
\hline ii)Other & & & & & & & \\
\hline
\end{tabular}

Source: Export Promotion Bureau, Bangladesh.

of getting a fair price for their garments. The average price of readymade clothing had dropped at least 15 per cent in European and American high streets, superstores and supply chains in the last 15 years, which should have been on the contrary [6]. Table- 1 shows export performance of Garment sector for the period of 2014-15 to 2015-16 (July to February).

In the 21st century, the garment sectors contribution to the export earnings has increased significantly compared to the other sectors. Exportoriented garment sector has provided employment opportunities to many workers from the poor socio-economic background, mainly women ${ }^{1}$ $[5,7]$. Female workers (\% of total labour force) in the RMG sector of Bangladesh were 40.12 percent in 2012, according to the World Bank2.

The health, safety and working condition of the workers in the garment sector is not at an international standard ${ }^{3}[8]$. The buildings and factories were not built to the standard which led to the collapse of the eight-story Rana Plaza building in

\footnotetext{
${ }^{1}$ Rampure, R. (2016). Case 2: Garment factory workers in Bangladesh need support, solidarity, not boycott, March 1, 2016 Retrieved from: http://rabble.ca/news/2016/03/garmentfactory-workers-bangladesh-need-support-solidarity-notboycott (date of access: 22 March, 2016).

2 World Bank (2012). Rtrieved from: http://www. tradingeconomics.com/bangladesh/labor-force-femalepercent-of-total-labor-force-wb-data.html (date of acess: 21 October, 2015).

${ }^{3}$ Rana Plaza tragedy miracle survivor builds new life, Case1. Retrieved from: http://www.aquila-style.com/focus-points/ rana-plaza-tragedy-miracle-survivor-builds-new-life/64201/ (date of access: 25 April, 2014).

Rahman, S. (2016). "319 RMG factories counting closure due to tough global competition”, Financial Express(Bangladesh),14 May.
}

Dhaka, Bangladesh on 24th of April 2013, killing 1,100 workers and injuring 2,500 who were sowing garments for large multinational companies and department stores of the developed countries of Australia, Europe and the US. Garment industry contributes to $80 \%$ of country's overall exports, employing nearly 4 million workers and is second only to China ${ }^{4}$. Figure- 1 illustrates a number of garments factories and employment in millions from the period of $1984-85$ to $2014-15$. It is observed that after 2012-13, the number of garment factories have decreased. Though in 201415 numbers of factories have been increased, but it is still below 2006-07 numbers.

As per BGMEA claim numbers of employees were 4 million, which may not be true as the number of garments factories decreased.

Bangladesh economy is also characterized with a high rate of unemployment [8]. A larger number of poor women are working in the garment sector at a very low wage and poor working conditions. Garments workers are the victims of torture and oppression by the factory owners who put them under pressure to meet the multinational deadlines. [9], in their research found that men and women from the poor slum areas worked for over nine hours of paid work, and that single women worked for longer hours than men and married women. The construction of the factory was not up to the standards to meet safety regulations and fire hazard. Thus, according to Bangladesh Garment Manufacturing Export Association, due to poor construction of the factories, fire broke

\footnotetext{
${ }^{4}$ Forbes Asia (2014). A Guide to Rana Plaza Tragedy and its implications in Bangladesh. Viewed 24-4-2014. Retrieved from: http://www.forbes.com/sites/alyssaayres/2014/04/24/a-guideto-the-rana-plaza-tragedy-and-its-implications-in-bangladesh.
} 


\section{EMPLOYMENTIN MILLION WORKERS $\square$ NUMBER OF GARMENT FACTORIES}

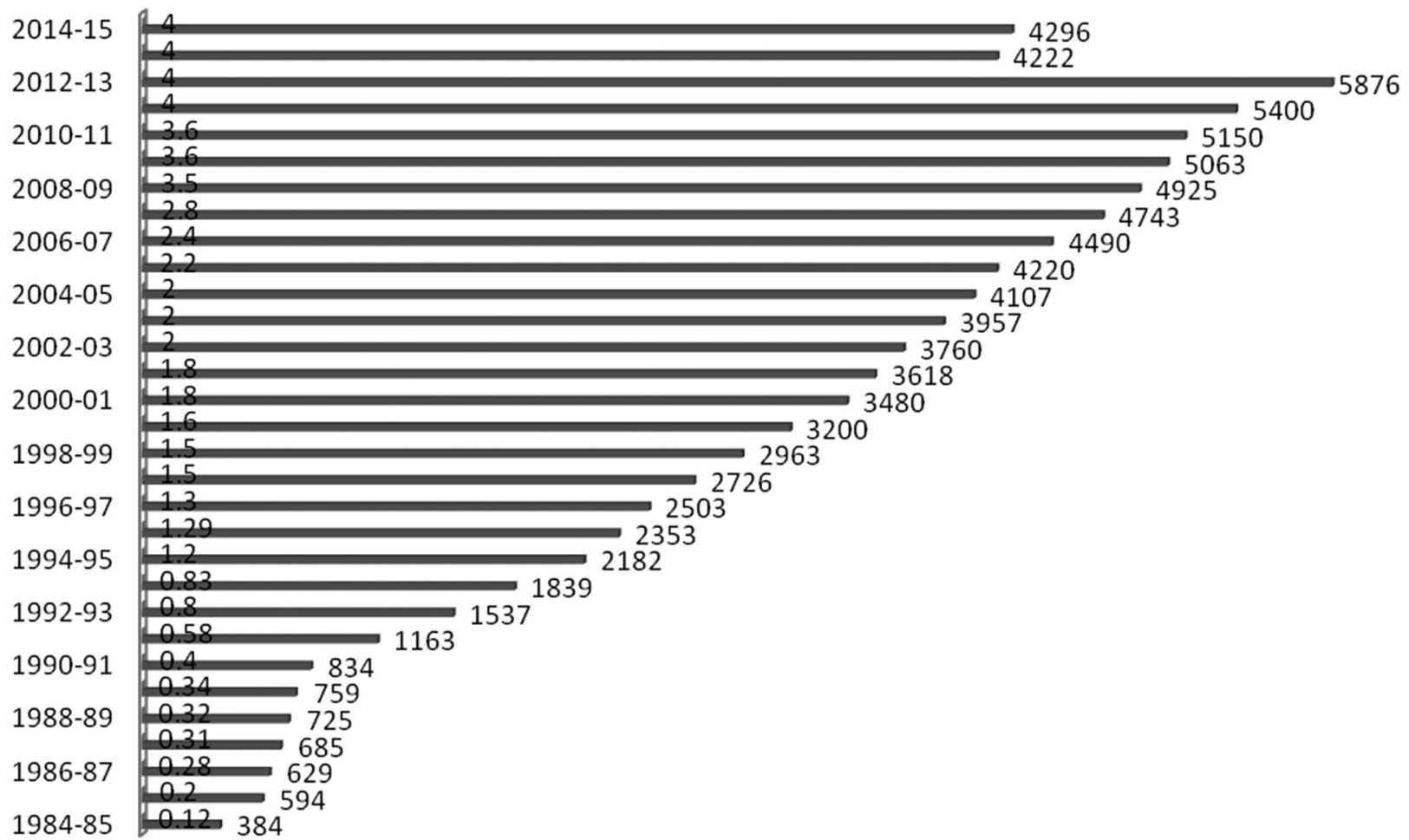

Source: Drawn by Authors' based on BGMEA

Fig. 1. RMG Factories and Employment

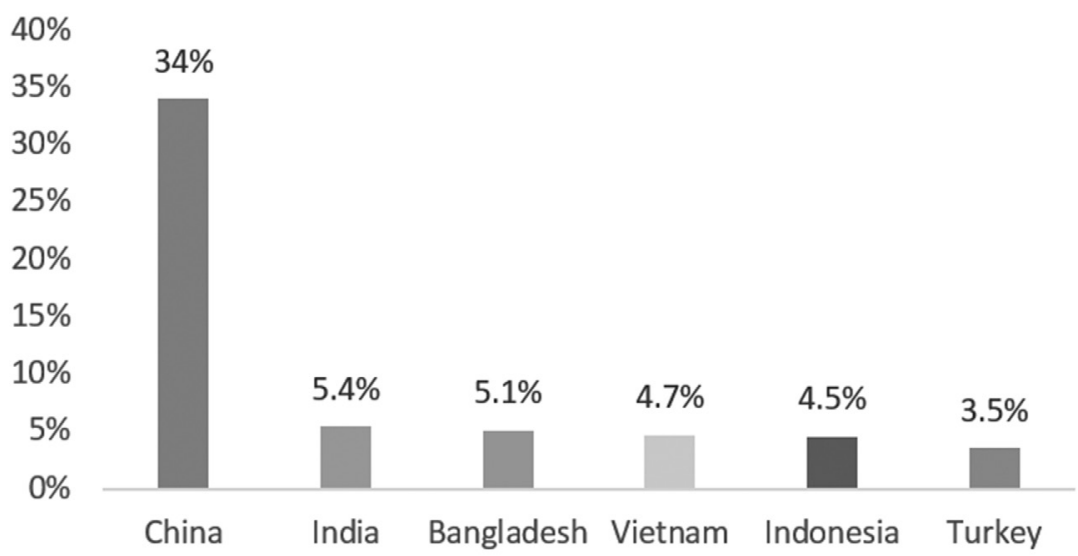

Source: United States International Trade Commission

Fig. 2. Global Apparel Market Share

out, and a large number of workers died between the periods of $1997-2015 .^{1}$

Figure- 2 above makes comparisons between different countries who are supplying apparels in the global market where China's market share is $34 \%$; India is $5.4 \%$ while Bangladesh has $5.1 \%$ of market share. It indicates a huge gap of $28.9 \%$ between China and Bangladesh's global apparel

\footnotetext{
${ }^{1}$ Ibid; World Trade Organisation (WTO) (2013). Retrieved from: athttp://www.wto.org/english/tratop_e/texti_e/texti_e. htm (date of access: 24 April, 2014).
}

market share and it is difficult for Bangladesh to reduce this gap. Figure- 3 illustrates the comparative positions of export of RMG products and the percentage of export of Bangladesh.

According to International Labour Organisation (ILO) $)^{2}$ in support of workers participation justified

2 Reddy, S. (2016). Better Work Bangladesh takes stock of progress and identifies way forward. Better Work Bangladesh held its first stakeholders and buyers forum in Dhaka (6 and 7 March). Retrieved from http://www.ilo.org/dhaka/Whatwedo/ Eventsandmeetings/WCMS_458057/lang--en/index.htm (date of access: 22 March, 2016). 


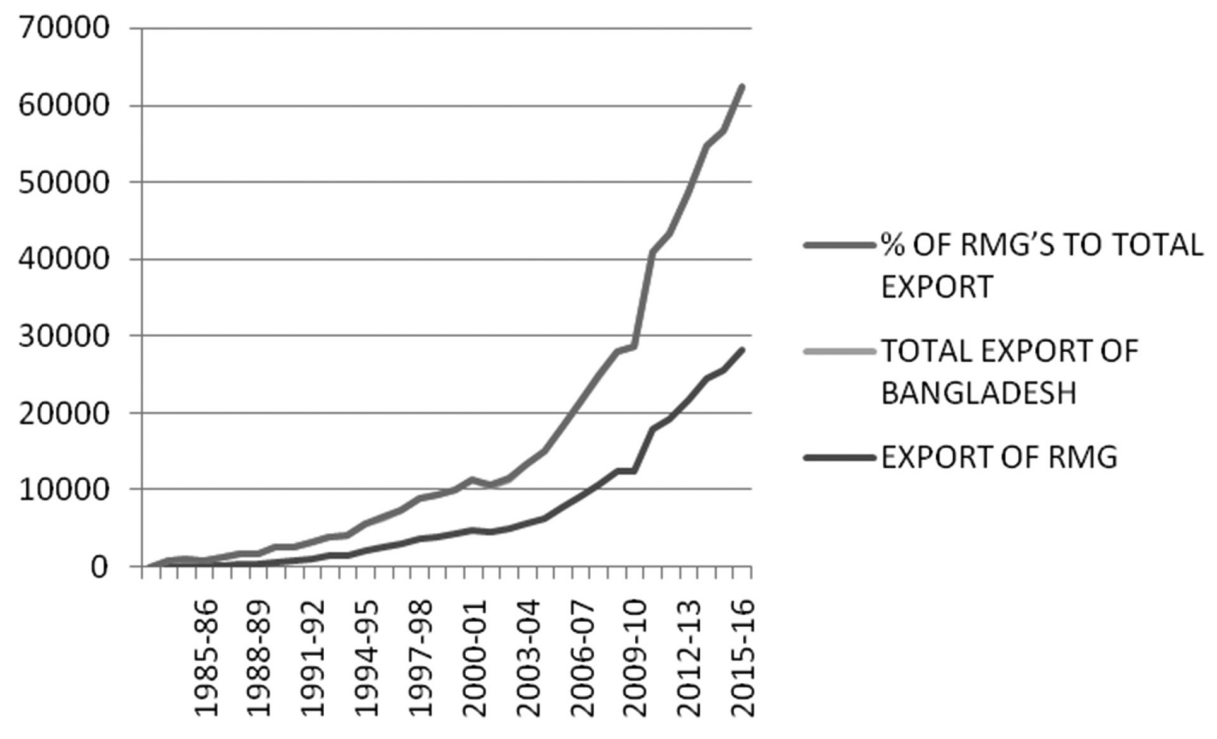

Source: Drawn by Authors' based on BGMEA -Export Promotion Bureau date (1985-86 to 2015-16)

Fig. 3. Comparative positions of export of RMG products and their percentage of export

that ... their point of view must be taken into account as regards to, day to day operation of the factory, because the workers who contribute to the production of goods and services, are sometimes at the risk of their health and even their lives. Bangladesh garment workers spend most of their life within the factory compound and depend upon it for their livelihood and so do their families. Therefore, with the increasing outsourcing and globalisation of capital, goods, services, factor market, such as labour market means that the various forms of employee participation would need to adapt to changes and the various challenges related to health, safety, socio-economic and working conditions and to bring their wages in line with the international standards, workers' rights and provide a work environment related to international health and safety laws and regulation. Further advancement of knowledge by invention and innovation and the diffusion of new ideas of workers' rights and safety, and finally the political will and commitment is necessary to remove economic backwardness, increase and enhance the human capabilities which are favourable for economic progress.

It had to be 'Rana Plaza Tragedy' and many such tragedies in the past, that made Bangladesh adopt the amendments to the labour act on 15th of July 2013, to protect the fundamental rights of the workers via collective bargaining and freedom of association to address the issues related to occupational workplace health and safety, which was reviewed in 2014 to confirm with the international labour standards.

According to the amendment, employees would no longer need approval from factory own- ers to form trade unions. Workers would just need to apply to the Labour Directorate for authorization. The amendment also allows trade unions to be formed in different administrative wings of a factory, which was not permitted under the existing Ministry of Law, Labour and Employment ${ }^{1}$. International Labour Organisation (ILO) is also stressing on Bangladesh government to fulfil its obligations and commitments on labour law reform since the Rana Plaza tragedy, to have spot inspections of health and safety conditions at workplace and creation of workplace Health Centres with over 5000 employees and safety welfare officers in workplace with more than 500 workers. ILO with partnership with the International Finance Corporation wing of the World Bank, is also working towards implementing 'Better Work Programme' in Bangladesh to mobilise the Bangladeshi government, trade unions and the employers, to improve productivity, working conditions health and safety and the rights of the workers in the garment industry².

'Better Work Bangladesh' program has gained excellent support from the government, workers and employers [10]. It is now working closely with almost 100 factories and we look forward to deepening and widening this engagement in the future. Examples of Better Work activities in Bangladesh include assessments and advisory visits conducted to develop compliance improve-

\footnotetext{
1 The government of Bangladesh, (GOB) (2003). A National Strategy for Economic Growth and Poverty Reduction, Ministry of Finance, Dhaka.

${ }^{2}$ International Labour Organisation (ILO) (2013). Retrieved from://www.ilo.org/global/about-the-ilo/media-centre/ statements-and-speeches/WCMS_218067/lang--en/index.htm.
} 
ment plans. Training is taking place on supervisory skills, financial literacy, industrial relations and workplace cooperation. Support has been provided to help build the capacity of government labour inspectors. In addition, draft guidelines have also been developed for forming Safety Committees in coordination with the Accord and Alliance. Canada, the Netherlands and the United Kingdom currently fund the Better Work programme in Bangladesh while the US Department of Labour and Switzerland support the programme in Bangladesh as well as globally ${ }^{1}[10]$.

Research question of the study is whether multinational companies are taking advantage of the absence of labour laws, workplace health and safety standards, building standards, long working hours and low wages in Bangladesh, where mainly millions of female workers are employed in the garment industry to sow garments for large department stores of the developed countries of Australia, Europe and USA? A most important question was raised by Quelch ${ }^{2} 12$ that should the responsibility of Western retailers and manufacturers extend beyond workplace safety to the human rights of workers in the factories of their contractors and subcontractors? He also answered that in a globally integrated economy, Western multinationals have the ability to exert more influence as a force for good than do any other stakeholders. Further suggested that the question, therefore, is not whether they should, but how quickly and effectively multinationals can work with factory owners, managers, and worker organizations in Bangladesh to implement improved safety and workplace conditions.

The first part of this paper provides introduction followed by a brief literature review (as much has been written by scholars from various socio, economic, political and ethical issues) related to the garment industry in context of export led orientation of the garment industry in Bangladesh, employment of women labour force and workplace health and safety.

Next, the paper focuses on the case of Rana Plaza tragedy; Objectives of the study and methodology; provides results of the opinion survey and also three related cases. The study then provides

\footnotetext{
${ }^{1}$ Bangladesh Economic Update, May 2014, Government Report, p.13; World Trade Organisation (WTO) (2013). Retrieved from: athttp://www.wto.org/english/tratop_e/texti_e/texti_e.htm, Viewed on 24 April, 2014; CIA. (2013). The World Fact Book (date of access: 28-4-2014), Retrieved from: https://www.cia. gov/library/publications/the-world-factbook/geos/bg.html.

${ }^{2}$ Quelch, John (2013). Bangladesh's Garment Factories Still Aren't Safe, Harvard Business Review, 21.
}

recommendations and implications, followed by future research directions and conclusions.

\section{Literature Review. Development of clothing industry in Bangladesh}

The export-oriented Garment industry according to the World Trade Organisation is worth US\$ 19 million per year, since the expiry in 2005 of an international agreement on textile and clothing import quotas and duty-free access by western countries ${ }^{3}$, clothing from low cost producing countries such as Bangladesh, Fiji, China and Mexico. In Bangladesh, the incidence of poverty decreased by $9.8 \%$ points during 2000-2005 (i.e. from 49.8 percent in 2000 to 40 percent in 2005) while the next five years (2005-2010) witnessed a decline from 40 percent in 2005 to 31.5 percent in 2010 i.e. by $8.5 \%$ points [10, p. 4]. Women participation in the Labour market in Bangladesh increased at the rate of 10.0 percent between 19992000 and $2010[10]^{4}$.

The numbers of employed women workers have increased from 7.9 million in 1999-2000 to 16.2 million in 2010 with an annual rate of 10.51 percent. The world famous micro-credit programme, originated in Bangladesh to help the poor women coming from landless families. The aim of the programme was to help the women financially to start a small business and be self-employed. For example, a loan was given to purchase a sewing machine, on the basis of group-based collateral which guaranteed the repayment of loan. These programmes have empowered women and opened up opportunities for self-employment in rural areas. However, social barriers to women's participation in paid work outside the home in non-farm activities still remain in rural areas. Although since the development of the garment industry there has been an increase in women's participation in the export led garment industry, however they are caught in a very low level of wage trap, which has become an easy way to exploit women work force [8]; [11].

A study by [12] explored and empirically compared the socio-economic backgrounds, wages and working conditions and contributions to household needs of women working for global markets such as the export-oriented RMG sector with those working for domestic markets, and

\footnotetext{
3 (WTO) (2013). Retrieved from: athttp://www.wto.org/english/ tratop_e/texti_e/texti_e.htm (date of access: 24 April, 2014).

${ }^{4}$ Rampure, R. (2016). Case 2: Garment factory workers in Bangladesh need support, solidarity, not boycott, March 1, 2016. Retrieved from: http://rabble.ca/news/2016/03/garmentfactory-workers-bangladesh-need-support-solidarity-notboycott (date of access: 22 March, 2016).
} 
Table 2

Comparative position of wage structure in the Garment factory in 1994, 2006, 2010 and 2013 (wages in US\$)

\begin{tabular}{|l|c|c|c|c|c|}
\hline Grade & $\begin{array}{c}\text { Wage 1994 } \\
\text { 1US\$ = Tk.40 }\end{array}$ & $\begin{array}{c}\text { Wage 2006 } \\
\text { 1US\$ = Tk.69.46 }\end{array}$ & $\begin{array}{c}\text { Wage 2010 } \\
\text { 1US\$ = Tk.70 }\end{array}$ & $\begin{array}{c}\text { Wage 2013 } \\
\text { 1US\$ = Tk.77.68 }\end{array}$ & $\begin{array}{c}\text { \% Change of wage } \\
\text { in 1994 to 2013 }\end{array}$ \\
\hline Grade: I & 117.5 & 74.0 & 132.86 & 167.35 & 42.43 \\
\hline Grade: II & 85.0 & 55.3 & 102.86 & 140.32 & 65.08 \\
\hline Grade: III & 52.5 & 35.3 & 58.86 & 87.60 & 66.86 \\
\hline Grade: IV & 42.8 & 32.4 & 53.76 & 82.65 & 93.11 \\
\hline Grade: V & 36.3 & 26.7 & 49.36 & 77.78 & 114.27 \\
\hline Grade: VI & 33.0 & 26.7 & 45.86 & 73.10 & 121.51 \\
\hline Grade: VII & 23.3 & 23.9 & 42.86 & 68.22 & 192.79 \\
\hline
\end{tabular}

Source: BGMEA. (Column: 6 was calculated by the authors).

concluded that mostly young women who are working in the RMG sector in the export processing zone (EPZ) of Dhaka come from poor families in rural areas. Although, garment sector has provided employment opportunities for rural women in EPZ, but also it is discriminating against very poor women, as these garment workers work for longer hours compared to those women working for domestic markets, further they also have to support their families in the villages [8]; [13]. Thus Bangladesh's comparative advantage continues to be its cheap labour; and competition puts pressure on the businesses to cut costs as much as possible-even at the price of worker safety, working conditions and low wages. Nonetheless, cheap labour does not or should not imply devaluation and disrespect of life itself of poor vulnerable skilled workers who are stitching garments for the first world developed countries under severe time line pressures.

Moreover, it is worth asking at this point whether short-term cost cutting objectives contrary to long term financial gain for the garment industry will benefit the economy? Given the commitment from the government and the factory owners will have a positive flow on effects on the economy. It will provide better health and safety working conditions, respect for workers to improve their quality of life and wellbeing and higher wages to improve the standard of living and per capita income of the garment workers in Bangladesh and thus avoid such Rana Plaza tragedies ${ }^{1}$ in the future. Wages in Bangladesh are still the lowest compared to the major RMG manufacturing countries in the world such as Fiji and Vietnam. Offices and factory building collapses due to poor building construction and structural issues are only symptomatic of overall poor working conditions and unregulated construction work

\footnotetext{
${ }^{1}$ Rana Plaza tragedy miracle survivor builds new life, Case1. Retrieved from: http://www.aquila-style.com/focus-points/ rana-plaza-tragedy-miracle-survivor-builds-new-life/64201/ (date of access: 25 April, 2014).
}

in Bangladesh [11]. Even though they are nowhere near desirable; standards of decent work, wages and working conditions have been improving slowly, given the international pressure. Enabling conditions for such improvements have been the economic upgrading by suppliers, mainly through functional upgrading and, not improvement in building, health and safety. These changes, in turn, have been facilitated by more stable relations with suppliers to the garment industry and have resulted in higher earnings per workers.

Readymade garment industry fully contributes to Bangladesh's goal of becoming a middle income country by 2021 and reach USD 50 billion in exports earnings. The RMG sector now needs to both build on its existing comparative advantages as well as keep innovating to resolve its longstanding challenges in terms of sustainable development $[14]^{2}$. Bangladeshi manufacturers need to go for innovation in making clothes rather than copying from others. They need their own brands, but during the process of achievement, entrepreneurs of RMG sector of Bangladesh should focus on not just minimising costs to achieve the target [15], but working conditions and fair wages. It was noted that nearly 618 factories shut down in the past three years after their productivities dropped due to various reasons. 319 more factories are also going to close down ${ }^{3}$. The garment sector is facing the challenges of gas and power crisis, high interest rate of bank loans, and devaluation of US dollar. He also pointed out that the sector was $3.19 \%$ below from the expected average growth and $5.19 \%$ points below from the expected growth for the 2021 target as reported in the Financial Express. As such considering the poor workers economic condition boycott won't solve the problem. If it happens, then it will have

\footnotetext{
${ }^{2}$ RMG Bangladesh (2015). RMG: Learning from the Chinese example. Retrieved from: http://rmgbd.net/rmg-learning-fromthe-chinese-example/ viewed (date of access: 8 January 2016).

${ }^{3}$ Rahman, S. (2016, May 14). 319 RMG factories counting closure due to tough global competition. Financial Express.
} 
divesting impact on garment workers livelihood as this will create pauperization process. ${ }^{1}$

\section{Case of Rana Plaza Tragedy}

Thousands of workers from poor socio-economic backgrounds are working in the export-led garment industry of Bangladesh. The health, safety and working condition of the workers is not protected in the garment industry. There is lack of regular inspection and compliance with local law in buildings and factories, which are not, built to the national and international construction standards. This led to the collapse of the eight story building-Rana Plaza [6] in Dhaka, Bangladesh on 24th of April 2013, "killing 1,100 workers and 2,500 injured", ${ }^{2}$ workers who were sowing garments for large multinational companies and department stores of the developed countries of Australia, Europe and USA.

The multinational companies are taking advantage of the absence of labour laws, workplace health and safety standards, building standards, long working hours and low wages in Bangladesh as can be seen from Table-2 shows a comparative wage structure of different grades/class of workers, where mainly millions of female workers are employed in the garment industry. Sinkovics, Hoque and Sinkovics (2016) found that the pressure for compliance has led the case companies to priorities the implementation of measurable standards over the socially grounded needs and priorities of workers. As such instead of adding new social value in fact destroyed previously existing social value as well as the pressure for compliance created the necessity to find ways to cover the sizable cost of compliance [16].

\section{Objectives of the study}

The main objective of the study was to focus on the garment sector after the Rana Plaza Tragedy: (1) To investigate the working conditions in the garment industry of the women; (2) To identify the main drawbacks of human resource management in the Garments industries; (3) To suggest recommendations for betterment of the workers status especially women workers in the garments industry.

\footnotetext{
${ }^{1}$ Rampure, R. (2016). Case 2: Garment factory workers in Bangladesh need support, solidarity, not boycott, March 1, 201. Retrieved from: 6 http://rabble.ca/news/2016/03/garmentfactory-workers-bangladesh-need-support-solidarity-notboycott (date of access: March, 2016).

${ }^{2}$ Forbes Asia (2014). A Guide to Rana Plaza Tragedy and its implications in Bangladesh. Viewed 24-4-2014. Retrieved from: http://www.forbes.com/sites/alyssaayres/2014/04/24/a-guideto-the-rana-plaza-tragedy-and-its-implications-in-bangladesh.
}

\section{Methodology}

The study was based on primary data collection. Primary data was collected by preparing two questionnaires-surveys i.e. one for women labourers and the second one for owners of the Garment industries. The survey was prepared in Bengali Language for the labourers and for industrialist it was in English. We used Cluster Sampling technique to choose the respondents. Total numbers of 300 surveys were distributed to the women workers. Out of which 249 surveys were returned, and only 222 surveys were duly filled and complete. The rest could not be taken as they were incomplete. On the other hand, we distributed 40 surveys to industry owners. Out of which, 32 surveys were returned, and 29 were duly filled. As such, these 29 surveys were selected. Remaining incomplete questionnaires could not be considered for data analysis. Total numbers of 222 women workers were accepted for the interview. Out of the 222 workers, 193 were from the Garments industries of the Dhaka district, while others were from Chittagong district. Out of 193 workers from Dhaka district, 9 workers were only from EPZ area. However, we distributed surveys questionnaire for women workers at sixty (60) garment industries of Dhaka and Chittagong District, including EPZ area. A total number of 29 industry owners' were interviewed. Out of which 22 were from the capital Dhaka, while 7 owners were from Chittagong district. Only one owner was interviewed from EPZ area of Dhaka. Time period of the study was 22nd June 2015 to 21st August 2015. Due to time and monetary constraints, we limited the sample size of women workers and garments owners interview. Actually, this research work was totally funded by the researcher's personal funds. No aid/grant for doing this research was taken for granted.

The following section provides analysis of the opinion survey from the garment workers and the owners of the garment industry. Three case studies will be included in this study.

\section{Findings and Analysis}

A total number of 222 women garment workers responded to the opinion survey. The demographics of the women garment workers as explained is as follows: Nearly $76.13 \%$ percent of respondents were married while unmarried were $23.87 \%$ percent. The level of education of $34.23 \%$ percent was below grade five while grade five to SSC level were $59.46 \%$ percent and above SSC to HSC (Grade 10-12) were $4.95 \%$ percent and those with education higher than HSC respondents were $1.36 \%$ percent. There were $2.70 \%$ percent of respondents up to the age of 20 years; while $59.01 \%$ 
were between 21 to 28 years; $25.68 \%$ were between 28 to 35 years; $9.91 \%$ were between 36 to 43 years and $2.70 \%$ were above 43 years. Out of these respondents $95.05 \%$ of respondents did have dependents, while $4.95 \%$ did not have any dependents and usually were exploited and made to work for long hours.

Those with one (1) dependent accounted to $8.53 \%$ of respondents; respondents with $2-3$ persons who depended on them were $81.04 \%$, and greater than 3 persons were $10.43 \%$ percent of respondents. In the case of living place of garment workers, unmarried workers living with family were $13.96 \%$, those living with husband /father-in-laws house were $19.37 \%$, mass accommodation sharing with other workers were $50.45 \%$ of respondents, single $13.06 \%$ percent and those loving with others were $3.16 \% .68 .92 \%$ of respondents said that prestige in the family of garment worker due to job rose, while $9.46 \%$ said that prestige and respect decreased due to working in the garment sector, and $21.62 \%$ of respondents said that prestige of the women workers remained the same. $30.18 \%$ of respondents agreed that social problems due to job occurred and increased; while $69.82 \%$ did not agree. $23.87 \%$ of respondents said that obstacles to work due to religion increased, while $76.13 \%$ did not agree with this statement. $41.44 \%$ percent of women respondents accepted that they had some authority and say in the family matters due to having employment in the garment sector, while unaccepted by $43.69 \%$ and hoped to get some say and authority in the future were accepted by $14.87 \%$. A total of $40.09 \%$ of respondents received net salary and benefits up to Taka 3000 per month, while in between Taka 3000 and Taka 4000 were $33.33 \%$ percent; $15.76 \%$ of respondents received salary between Taka 4001 and 5000, while $7.66 \%$ of respondents received salary between Taka 5001 and Taka 6000, and finally $2.25 \%$ of respondents received salary between Taka 6001 and Taka 7000 . Those who received more than Taka 7001 were $0.91 \%$. Satisfaction on salary and benefits was received by $38.74 \%$ of respondents and were not at all satisfied while $56.3 \%$ were partially satisfied and fully satisfied were only $4.95 \%$ percentage. Regarding the question on child care arrangements made by garment factory, $14.89 \%$ were satisfied, while nearly $23.41 \%$ were relatively satisfied. Satisfied neighbours were $53.19 \%$ and others were $8.51 \%$ percent. $7.66 \%$ of respondents used recreation arrangements made by garment factory, workers who made their own arrangements were $86.04 \%$ and with no arrangements were $6.30 \%$.

Table- 3 gives results of the women garment workers opinion survey. Among the respondents' only $4.96 \%$ worked for 8 hours. Greater than 8 hours but below 10 hours were only $13.06 \%$ of respondents. Those who worked for more than 10 hours were $33.78 \%$, while in between 11 and 12 hours were $48.20 \%$ of respondents. Only $3.60 \%$ got weekly holidays while $96.40 \%$ did not have any weekly holidays. Before joining service only $14.86 \%$ had job training while $85.14 \%$ did receive some on job training. Evaluation of work was done on the basis of hard work supported by $9.46 \%$ of respondents while quantity of works were supported by $17.57 \%$ of respondents; $10.36 \%$ of respondents supported quality of work, while both quantity and quality of work was supported by $54.05 \%$ of respondents; Good relations with owners and senior staff was supported by $8.56 \%$ of respondents.

Wage increment occurred as opined by the respondents depends on showing an increase in product/output was supported by $4.95 \%$; while doing more work was supported by $46.40 \%$ and expertise and specialization in work were supported by $37.39 \%$ and good relations with owners and senior staff were supported by $11.26 \%$ of respondents. Other benefit was supported by $91.89 \%$ of respondents while $8.11 \%$ did not support. Motivation for doing work was supported by $4.95 \%$ while higher remuneration was supported by $12.61 \%$. Physical security at work was supported by $7.66 \%$; Job security was supported by $25.23 \%$ and livelihood security works as $45.50 \%$ and appreciation at work was supported by $4.05 \%$. Out of these respondents $30.18 \%$ of workers worked up to 1 year while more than one, but less than five years were $47.75 \%$ and those who worked for more than five years were $22.07 \%$. Overall working environment was satisfactory towards $32.88 \%$ percent while unsatisfactory towards $67.12 \%$ of workforce.

Regarding security, safety from uncertainty and emergency $5.41 \%$ of respondents were satisfied; while $94.59 \%$ were unsatisfied with the arrangements. $8.56 \%$ of respondents had an alternative job/source of income, while $91.44 \%$ of respondents did not have any other source of income. Selfefficiency and effectiveness were supported by $59.46 \%$ of respondents, while $40.54 \%$ of respondents did not support. Health and safety training program was arranged for $61.71 \%$ of respondents while $38.29 \%$ percent did not receive any health and safety training programs. Awareness of women workers regarding Bangladesh Labor Amendment Act $2013^{1}$ were only accepted by $10.81 \%$ of re-

\footnotetext{
${ }^{1}$ Ministry of Labour and Employment, GOB. (2013). Retrieved from: http://www.mole.gov.bd/index.php?option=com_con
} 
Results of the women garment workers opinion Survey

\begin{tabular}{|c|c|c|c|}
\hline Description & Category & Total Number & Percentage \\
\hline \multirow{4}{*}{ Hours of work per day } & (a) 8 hours & 11 & 4.96 \\
\hline & (b) $>8$ hours & 29 & 13.06 \\
\hline & (c) $>10$ hours & 75 & 33.78 \\
\hline & (d) $11>12$ hours & 107 & 48.20 \\
\hline \multirow{2}{*}{ Weekly holiday } & (a) Yes & 8 & 3.60 \\
\hline & (b) No & 214 & 96.40 \\
\hline \multirow{2}{*}{ Job training } & (a) Before joining service & 33 & 14.86 \\
\hline & (b) On job training & 189 & 85.14 \\
\hline \multirow{5}{*}{ Work Evaluation } & (a) Hard work & 21 & 9.46 \\
\hline & (b) Quantity of work & 39 & 17.57 \\
\hline & (c) Quality of work & 23 & 10.36 \\
\hline & (d) Both quantity \& quality of work & 120 & 54.05 \\
\hline & $\begin{array}{l}\text { (e) Good relations with owners and } \\
\text { senior staff }\end{array}$ & 19 & 8.56 \\
\hline \multirow{4}{*}{ Wage increment } & (a) Showing output & 11 & 4.95 \\
\hline & (b) Doing more work & 103 & 46.40 \\
\hline & (c) Expertise in work & 83 & 37.39 \\
\hline & $\begin{array}{l}\text { (d) Good relations with owners and } \\
\text { senior staff }\end{array}$ & 25 & 11.26 \\
\hline \multirow{2}{*}{ Other benefits } & (a) Yes & 204 & 91.89 \\
\hline & (b) No & 18 & 8.11 \\
\hline \multirow{6}{*}{ Motivating factors } & (a) For doing work & 11 & 4.95 \\
\hline & (b) Higher remuneration & 28 & 12.61 \\
\hline & (c) Physical security & 17 & 7.66 \\
\hline & (d) Job security & 56 & 25.23 \\
\hline & (e) Livelihood security & 101 & 45.50 \\
\hline & (f) Appreciation & 9 & 4.05 \\
\hline \multirow{3}{*}{ Years of service } & (a) Up to 1 year & 67 & 30.18 \\
\hline & (b) $1-5$ years & 106 & 47.75 \\
\hline & (c) $>5$ years & 49 & 22.07 \\
\hline \multirow{2}{*}{ Overall working environment } & (a) satisfactory & 73 & 32.88 \\
\hline & (b)unsatisfactory & 149 & 67.12 \\
\hline \multirow{2}{*}{ Security, safety for uncertainty and emergency } & (a) Yes & 12 & 5.41 \\
\hline & (b) No & 210 & 94.59 \\
\hline \multirow{2}{*}{ Alternative job/source of Income } & (a) Yes & 19 & 8.56 \\
\hline & (b) No & 203 & 91.44 \\
\hline \multirow{2}{*}{ Self-efficiency } & (a) Yes & 132 & 59.46 \\
\hline & (b) No & 90 & 40.54 \\
\hline \multirow{2}{*}{ Health Training program } & (a) Yes & 137 & 61.71 \\
\hline & (b) No & 85 & 38.29 \\
\hline \multirow{2}{*}{ Awareness of women [29] labour act2013 } & (a) Aware & 24 & 10.81 \\
\hline & (b) Unaware & 198 & 89.19 \\
\hline \multirow{2}{*}{ Fire safety system at the garment factory } & (a) Yes & 43 & 19.37 \\
\hline & (b)No & 179 & 80.63 \\
\hline
\end{tabular}

Source: Developed for this research.

spondents, while $89.19 \%$ of respondents were not aware of this amendment. $19.37 \%$ of respondents supported to having fire safety systems at the garment factory while $80.63 \%$ of responded that they did not have safety measure from fire and the factor building collapsed.

tent\&task=view\&id $=475 \&$ Itemid $=543$ (retrieved from: 21 st October), (Bengali).
Results of the opinion survey of owners of the garment industries are given in Table-4. Out of the twenty nine (29) owners, $24.14 \%$ had ISO9000 certification. While $75.86 \%$ said that they did not have ISO-900 certification. $41.38 \%$ of owners thought that they have already taken good initiatives to improve working environment while no initiatives were supported by $24.14 \%$ of owners and those owners who supported and took in- 
Results of the opinion survey of owners of the garment industries

\begin{tabular}{|c|c|c|c|}
\hline Description & Category & Total Number & Percentage \\
\hline \multirow{2}{*}{ ISO-9000 Certification } & (a) Yes & 7 & 24.14 \\
\hline & (b) No & 22 & 75.86 \\
\hline \multirow{3}{*}{ Initiative to improve Working environment } & (a) Yes-Good & 12 & 41.38 \\
\hline & (b) No initiatives & 7 & 24.14 \\
\hline & (c) Initiative are taken & 10 & 34.48 \\
\hline \multirow{3}{*}{ Hours of work per day } & (a) $>8$ hours & 6 & 20.69 \\
\hline & (b) $>10$ hours & 19 & 65.52 \\
\hline & (c) $>12$ hours & 4 & 13.79 \\
\hline \multirow{3}{*}{ Efficiency and Effectiveness of women workers } & (a) Good & 20 & 68.96 \\
\hline & (b) Medium & 7 & 24.14 \\
\hline & (c) Bad & 2 & 6.90 \\
\hline \multirow{2}{*}{ Wages in terms of productivity } & (a) Satisfactory & 29 & 100 \\
\hline & (b) Unsatisfactory & 0 & 0 \\
\hline \multirow{3}{*}{$\begin{array}{l}\text { Opportunity to contribute to decision making process by } \\
\text { worker }\end{array}$} & (a) Always & 0 & 0 \\
\hline & (b) Sometimes & 4 & 13.79 \\
\hline & (c) Never & 25 & 86.21 \\
\hline \multirow{3}{*}{ Women workers contribution to society } & (a) Yes & 11 & 37.93 \\
\hline & (b) No & 10 & 34.48 \\
\hline & (c) Partially & 8 & 27.59 \\
\hline \multirow{2}{*}{ Day child-care arrangement } & (a) Yes & 4 & 13.79 \\
\hline & (b) No & 25 & 86.21 \\
\hline \multirow{2}{*}{ Recreation arrangement } & (a) Yes & 6 & 20.69 \\
\hline & (b) No & 23 & 79.31 \\
\hline \multirow{2}{*}{ Compliance of the Bangladesh labour amendment act 2013} & (a) Yes & 3 & 10.34 \\
\hline & (a) No & 26 & 89.66 \\
\hline \multirow{2}{*}{$\begin{array}{l}\text { Requirement by the women workers other than the work of } \\
\text { the industry }\end{array}$} & (a) Yes & 1 & 3.45 \\
\hline & (b) No & 28 & 96.55 \\
\hline \multirow{2}{*}{ Fire safety and security system } & (a) Yes & 26 & 89.66 \\
\hline & (a) No & 3 & 10.34 \\
\hline
\end{tabular}

Source: Developed for this research.

itiatives were supported by $34.48 \%$ of owners. More than Eight (8) hours of work per day was supported by $20.69 \%$ while more than ten hours was supported by $65.52 \%$ of owners, and more than twelve hours were supported by $13.79 \%$ of owners. Efficiency and effectiveness of women works were good and was supported by $68.96 \%$ respondents while $24.14 \%$ of owners thought that it was at medium level and $6.90 \%$ thought that efficiency and effectiveness was bad. $29 \%$ of owners responded that wage in terms of productivity were satisfactory. Opportunity to contribute to decision making process by worker sometimes was supported by $13.79 \%$ of owners/respondents, while never supported by $86.21 \%$ of respondents. A women workers contribution to society was supported by $37.93 \%$ of owners, while $34.48 \%$ did not support and was partially supported by $27.59 \%$ of owners. Availability and provision of day Childcare arrangement was supported by $13.79 \%$ while
$86.21 \%$ did not provide any day care arrangement. Recreation arrangements made by owners was supported by $20.69 \%$ while $79.31 \%$ of factory owners did not provide and support any day-childcare arrangement. Compliance of the Bangladesh labour amendment act $2013^{1}$ was supported by $10.34 \%$ of factory owners, while $89.66 \%$ did not provide any compliance to the amended labour law.

Requirement by the women workers other than the work of the garment industry was supported by $3.45 \%$ while $96.55 \%$ did not support. Need of essential fire safety and security systems requirement and compliance was supported by $89.66 \%$ of factory owners, while $10.34 \%$ of owners who participated in the survey, did not support the need for compliance with fire safety and security systems.

${ }^{1}$ Ibid. 


\section{Case-1: Rana Plaza tragedy miracle survivor builds new life ${ }^{1}$}

Quote: "She was the "miracle" seamstress, plucked from the rubble of the world's worst garment factory disaster 17 days after the building collapse. One year on, she has married and found a new job. The case of Reshma Akhter, 19, was a rare bright spot in the Rana Plaza catastrophe on the outskirts of the Bangladeshi capital Dhaka on 24 April last year that left 1,138 dead and more than 2,000 injured. Images of her, dusty and dazed, being pulled from the wreckage appeared on newspaper front pages worldwide and turned her into a national heroine. Like thousands of other survivors - as well as the rescuers who faced appalling scenes, often having to perform impromptu amputations on the spot-Reshma still suffers from insomnia and panic attacks. But she married her boyfriend in a simple ceremony in her village in northern Bangladesh in February and is enjoying a new job in a hotel run by the international chain Westin, which approached her after her ordeal. "I enjoy the job. This is completely the opposite of the work of a garment factory. The job is sober and relaxed," she said, adding that she would never set foot in a clothing factory again. She had joined one of the five factories in Rana Plaza just 22 days before it caved in. Her basic monthly salary was 4,700 taka (\$60) working a 10 -hour daily shift. A year later, she said she has not received any compensation from a trust fund financed by Western retailers to compensate survivors, which has received only $\$ 15$ million instead of a targeted $\$ 40$ million. "I only got some money from the prime minister and private donors," she said, adding that despite the trauma she still suffers, she is looking forward to life with her husband and plans to move into a bigger home with him."We knew each other for years, as we had been neighbours. He is a good guy and cares for me." (Unquote)

Observation: Rana Plaza tragedy is a horrible scenario for Bangladesh. It reflects some greedy profit suckers who want to make profit at the cost of life of poor garments workers.

This is against humanity, unethical and immoral. However, for the Reshma who is a miracle survivor, we hope that she will have a nice life despite tragic incident. More effective help and assistance to rehabilitation procedure for the tragic survivors around 2500 injured like Reshma should be arranged as a part of CSR by the private sector and NGOs should come forward with collabo-

\footnotetext{
${ }^{1}$ Rana Plaza tragedy miracle survivor builds new life, Case1. Retrieved from : http://www.aquila-style.com/focus-points/ rana-plaza-tragedy-miracle-survivor-builds-new-life/64201/ (date of access: 25 April, 2014).
}

rative approach. There may be a strategic alliance between public-private and Foreign strategic alliances to help victims.

\section{Case-2: Garment factory workers in Bangladesh need support, solidarity, not boycott ${ }^{2}$}

Quote: "When I think of Bangladesh, the disaster at Rana Plaza is the first thing that comes to mind. On April 24 2013, a factory building on the outskirts of Dhaka collapsed, killing over 1,100 workers and injuring over 2,500 more."

Canadians were appalled to find that familiar brands such as Joe Fresh, an off-shoot of Labour laws, had been sourcing from a factory building where conditions were so bad that workers said they had been beaten to go back to work after cracks had been seen appearing in the walls and ceiling. Canadian consumers - and consumers of cheap Ready Made Garments (RMG) all over the global north-have had to face that workers in faraway Bangladesh were paying the price for our collective appetite for cheap clothing. As part of a recent trade union delegation from CUPE, PSAC, USW, Uniform and the CLC to visit Bangladesh, a number of us Canadian trade unionists were able to see the chaos of this densely populated city for ourselves as we met with workers and activists from the RMG sector.

We need to offer our concrete solidarity to those who are fighting to ensure that the RMG factory workers in Bangladesh have safe working conditions, decent wages and benefits and access to the services they need to live their lives with dignity. Their fight is part of a global struggle against capitalism that Canadian workers are also a part of: they are just on the front lines of it in way that we are not. Our solidarity cannot just be the small organizing projects that Canadian unions can support in Bangladesh: that is merely one aspect of our solidarity. Such solidarity projects help organizations like the Bangladesh Center for Worker Solidarity, which operate on shoe strings, and yet have incredible reach and impact.

But there is also a need for us to stay engaged, to engage the Canadian and Bangladeshi governments around trade policy in ways that help Bangladeshi workers and that we continue to monitor the developments in building safety and workers' rights. Transnational brands that sell RMGs in Canada need to know that we care not just about building safety but also about the human rights

\footnotetext{
2 Rampure, R. (2016). Case 2: Garment factory workers in Bangladesh need support, solidarity, not boycott, March 1, 2016. Retrieved from: http://rabble.ca/news/2016/03/garmentfactory-workers-bangladesh-need-support-solidarity-notboycott (date of access: 22 March). 2016.
} 
of workers. Our trade policy needs to reflect this. Four years after the Tazreen fire and approaching the third anniversary of the collapse of Rana Plaza, it is now more important than ever to let the brands, the factory owners and the Canadian and Bangladeshi government know that we are watching." (Unquote)

Observations: Archana rightly observed that foreign buyers should not boycott RMG products from Bangladesh rather they must express solidarity and support. Moreover, the author opined that human rights of the laborers are more important than building safety for which trading policy of Canada provides some ethical guidelines. As such fair price for the RMG sector product should be attained so that income level of the laborers can be raised.

\section{Case-3: Three years after Rana Plaza disaster, has anything changed? [20]}

Quote: "Three years after the Rana Plaza disaster in Bangladesh that killed more than 1,100 factory workers, the rights and safety of workers are in greater focus, but progress in fixing problems in the supply chain is slow, experts and activists say. Global fashion retailers say the tragedy prompted them to work together more closely to protect workers in developing nations and ensure the safety of buildings. There has also been legislation to ensure greater supply-chain transparency. «You have about 200 brands working together, and there's definitely more transparency, more attention to the issue of human rights in the global supply chain,» Sarah Labowitz, co-director of the Center for Business and Human Rights at the NYU Stern School of Business in New York, told the Thomson Reuters Foundation." But in addressing fire safety, building safety, workers' protection - there aren't enough practical discussions around these issues, not enough financing. So not enough has changed,» said Labowitz. The reasons identified were the following: low wages, behind schedule, tinder-box and ethical consumers.

\section{Low Wages}

The duty-free access offered by Western nations and low wages for its workers helped turn Bangladesh's garment exports into an industry with $\$ 25$ billion in annual revenue. Sixty percent of the clothes go to Europe, 23 percent to the United States and 5 percent to Canada. The minimum monthly wage for garment workers in Bangladesh is $\$ 68$, compared with about $\$ 280$ in mainland China, which nevertheless remains the world's biggest clothes exporter. British budget fashion chain Primark, which was sourcing some clothing from Rana Plaza, said companies had recognized the need to ensure that workers were paid fairly and conditions were good, but building safety had not been an issue.

\section{Behind Schedule}

The disaster led to the creation of two international coalitions designed to assess and help fund improvements to building and fire safety at thousands of garment factories in Bangladesh. Most European retailers signed up to an Accord on Fire and Building Safety in Bangladesh, which oversees more than 1,600 factories used by retailers like H\&M, Marks \& Spencer and Primark. Accord inspectors set out structural, electrical and firesafety improvement plans for most of the factories. But nearly three years on, about 70 percent of those plans are behind schedule, according to data on its website.

\section{A Tinder Box}

In neighbouring India, also a hub for clothing manufacture and export, retailers H\&M, Inditex, C\&A and PVH committed earlier this year to improving the lives of workers in the southern city of Bengaluru, after a report said employees lived in appalling conditions and were denied decent wages and freedom of movement.

\section{Ethical Consumers}

As well as companies and governments, consumers are getting involved in the campaign for greater supply-chain transparency. Global retailers' efforts will have little impact unless consumers demand more ethically produced goods. Fashion Revolution, a UK-based charity established in response to the Rana Plaza disaster, has popularized the Twitter hash tag \# who made my clothes, while The Human Thread Campaign, similarly set up after the disaster, asks Catholics to reflect on the origin of their clothes. «Politically, socially, there's a big debate about the real cost of globalization," (Unquote)

Observations: Labowitz rightly observed that the RMG sector should need to be supported for the sake of the labours as they are largely dependent on this sector through income distribution at least theory of second best applied in the micro level of income and consumption pattern of the family members of the labourers. Kaldor-Hicks compensation criteria based on the thought that people could be compensated also applied through working in this sector though some exploitation. Further micro level foundation has greater macroeconomic impact as it will have accumulated impact on the National income accounting process. 
However, not only in Bangladesh but also this type of labour exploitation prevails in other developing countries. Fair pricing is needed in international trading for ethical and moral obligations of the buyers to ensure sustainability of production of products.

Brief findings for Rana Plaza related cases:

This is unfortunate that Savar Rana Plaza tragedy occurred due to human grid. Not only industry owners failed to safe guard the interest of the human being. But BGMEA, NGOs, Foreign buyers, members of the civil society and women labourers are not actually interested so that victim and their family members get due compensation. Irony is this taking the advantage of this Savar Rana Plaza tragedy a section of foreign buyers pressing hard for decreasing the purchasing rate of the RMG products from Bangladesh. Moreover, middlemen are trying to suck the compensation benefits. Alliance for USA buyers and Accord for European buyers working at Bangladesh after Savar Rana Plaza tragedy but they do not happy relationship for last 3 years with the Garments factories owners. They examine the factories, found fault, and stipulate CAP's to arrange to create the garments factories secured. But proprietors complain against them, pointing out that they have been working beyond their jurisdiction; unprofessionally engage labour matter, works as trade union.

\section{Recommendations and Policy Implications}

Women in the garment industry of Bangladesh are contributing to the growth of the garment industry and the export-led sector of the economy, contributing billions of dollars to the national economy. Their participation in the workforce has contributed to the improvement of their socio-economic status and empowerment at home, work place and in decision making process. Much needs to be done to ensure their health and safety at work place to avoid future Rana Plaza tragedies as well as job security and provision of pension at retirement. The following recommendations are provided:

- Workplace health and safety in terms of workspace, fire alarm, building safety should be made compulsory according to international standards with six monthly inspections.

- Insurance schemes for workers at workplace should be arranged by the firm.

- Six days working week and one day holiday based on roster. Eight hours working day, lunch break for 30 minutes and morning and afternoon tea break for 15 minutes.
- Paid annual leave along with paid sick leave and maternity leave must be given, along with long term job security and provision for tenure.

- Implantation of labour law-2013. Minimum wage laws, factory law of 1965 and Bangladesh Labour (amendment) act of 2013 should be modified and enforced in all the garments industries based on changing global environment. ${ }^{1}$

- Purchasing Power parity should be considered at the time of fixing the wages. As such minimum wage rate of each woman labour may be fixed at Tk. 9500/- per month. Overtime payment must also be ensured.

- Day care facility and health and nutrition for the children below the age of six years should be arranged for women workers children. Living accommodation at an affordable rate in a clean environment must be arranged.

- On the job training facilities and career progression and promotion opportunities.

- All the factories must have ISO 9000 certification.

- Transportation facilities should be arranged for workers who work overtimes.

- The police officials of different police station may initiate further safety arrangement at workplace and at their place of accommodation.

- Investment in human capital is necessary to establish to provide in service training and research. Owners of the garment industry should invest more on education and training of women workers. Such as establishment of night schools, correspondence courses so that they can be trained on weekly holidays. Open University may try to introduce such vocational courses in fashion designing the garments to meet the global demand.

- Owners of the business should take the responsibility to motivate, recognise and reward the innovative women workers. They should feel that they are being appreciated which will give them a sense of participation, identification and sense of belonging to an industry which protects their rights, health and safety and is also concerned about their children so that they can be motivated and have a feeling loyalty to the garment factory.

- Government should nationally recognise and acknowledge through national awards on independence day or international women's day the contribution made by the women labour force to the lucrative export industry and gross domestic product.

\footnotetext{
${ }^{1}$ Ministry of Labour and Employment, GOB. (2013). Retrieved from: http://www.mole.gov.bd/index.php?option=com_con tent\&task=view\&id=475\&Itemid $=543$ (date of access: 21 st October), (Bengali).
} 
- BGMEA must keep official record about women workers who are bullied, tortured, attacked and raped whether at the premised of work or outside. They should get financial, legal health, as well as mental support from the BGMEA and NGOs and a separate section should be opened in the BGMEA run by women for women.

- Labour productivity in the Garments sector must be improved by improving the working condition, air-conditioning, staff room facility, health and safety, adopting new technology and sewing machines, training for staff, which will improve Capacity utilization. Lead-time should be matched with demand for greater increasing efficiency and speed in the global business processes.

- Rehabilitation program of the unemployed person from Garments sector owing to the exit from the garments business should be taken as a precautionary measure. As such training and development program for the garments workers is required so that if they fall victim of retrenchment from the job, then they can find alternative way for their livelihood. Thus social compensation and safety net programme for the garments workers should be made mandatory.

- Some firms are now closing due to facing difficulties of compliances. As such exit plan must be taken for those owners who cannot comply with compliances or cannot be able to remain in business in the competitive scenario.

\section{Future Research Directions}

A study may be conducted based on following segments i.e. those who are the victim of Rana Plaza tragedy; existing workers; Union leaders; NGO representatives; existing garment owners of the country; unsuccessful factor owners; foreign buyers; other external stakeholders. For future research direction a qualitative survey will be administered to the suppliers and the workers with some policy recommendations. Plan-DoCheck-Act process in the RMG sector is required for continuous improvement to attain competitive advantage.

\section{Conclusions}

Developing country such as Bangladesh which depends on export-led growth via the garment industry should aim to have pro-poor inclusive development strategy, which protects the rights of the garment workers, particularly women. The local RMG industry owners and the key stake holders from the supply side should work with the government as well as with the large multinational corporations within the framework of international labour laws and human rights, where gar- ment workers and workers from all nationals and multinationals industries in Bangladesh are also informed about the employment laws, health and safety issues, overtime wages, working hours and conditions, minimum wages and ethical and legal compliance of the factory towards the workers. ${ }^{1}$ Saxena (2010) found that investment in infrastructure to improve lead times and facilitate trade is the key to Bangladesh's competitiveness, developing and implementing supportive policies, and improving governance at the national and factory levels is also crucial [19] for competitiveness and long run sustainability together with compliance with security, health and safety.

Without adding value in the global value chain for long run, competitors may create bottleneck to raise productivity. However, we do not believe that Bangladesh's big market in the UK will be under pressure due to recent UK-EU membership referendum which referred to as 'Brexit'. Reason behind this predication is that volume and quantity of our trading patterns of UK indicates that we are mostly exporting low value addition garments product to UK. As such after the "Brexit" is executed, Bangladesh will have to go for new trading agreements independently with UK. Entrepreneurs of RMG sector should put special emphasis on garment industry 'Development with a Human Face' and adopt a humanistic framework for the garment workers and motivate them to inculcate ownership of their organizations. Accomplishment of extended sustainability of the RMG sector is possible through regional cooperation under BIMSTEC, and free trade area can be developed. But BIMSTEC is now more or less ineffective. As such leaders of the member countries should come forward with true spirit to upgrade stronger ties among member countries under the BIMSTEC regional trade bodies.

Public-private-foreign (PPF) collaboration in this sector will be beneficial not only for entrepreneurs of this sector but also RMG labourers' especially at the micro level it also raises income level and purchasing power. Fair price should be ensured for improving the living condition of the RMG workers. It is over three years since the post Rana Plaza tragedy and thus health and safety of the work environment should not be compromised at any cost to sustain the employment and livelihood of the workers but also the export-led garment industry of Bangladesh which feeds the global branded garment and fashion industry supply chain. If such exploitation of garment women workers continues then the consumers of

\footnotetext{
${ }^{1}$ Ibid.
} 
these garments from developed countries should start a campaign of ethical purchase of RMG from those countries who provide health, safety measures, do not exploit women and children and follow the international labour law and construction standards, similar to the campaigns where carpets woven by children are banned for export market and likewise coffee and tea which is grown and picked by exploiting children and women labourers. Stiglitz pointed out that globalization has enhanced the opportunities for success, but it has also posed new risks for developing countries. The rules of the game have been designed for the most part by the advanced industrial countries, or more accurately, by special interests in those countries, for their own interests, and often do not serve well the interests of the developing world, and especially the poor [20]. Further, the Bangladesh Government needs to work in cooperation with the local factory owners and key stake holders in Bangladesh, multinational garment sector, International Labour Organisation, World Bank, World Trade Organisation and the European Union to develop and implement the new amendments to the labour laws, collective bargaining, workplace health and safety training, on the spot inspections, building construction standards to ensure safe and secure work environment in order to prevent future tragedies in the RMG industry and protect the garment workers rights particularly women. Because, they are not only the wage/ bread earners to provide finance, food, clothing and shelter to their families and the key foreign exchange earner for the owners of the garment factory and the economy, but also on whom the multinational companies depend to produce /sew RMG under pressure, in a timely manner, to international market standards to meet the demands of the ever growing fashion industry in the developed world.

\section{References}

1. Ahmed, F. E. (2004). The Rise of the Bangladesh Garment Industry: Globalisation, Women Workers, and Voice. NWSA Journal, 16(2), 34-45.

2. Rhee, Y. W. (1990). The catalyst model of development: lessons from Bangladesh's success with garment exports. World Development, 18(2), 333-346.

3. National Human Rights Commission, Bangladesh. (2013, June). Security and Safety Net of Garments workers: Need for Amendment of Labour Law, 18.

4. Ahmed, S. R. M., \& Islam, N. (2013). Labour Unrest in the Ready-Made Garment Industry of Bangladesh. International Journal of Business and Management. Canadian Centre of Science and Education, 8(15), 68-79.

5. Berget, A. (2011). Bangladesh's ready-made garments landscape: The challenge of growth. McKinsey \& Company Report, 4-19.

6. Alam, M. S. (2016). Dialogue on Sustainable Workforce and Supply Chain Reforms for Vision 2021. Conference on 'Ethics, Efficiency and Productivity in the RMG sector: Towards $\$ 50$ billion Exports 2021' Organized by University of Dhaka, Monash University, and University of Warwick, UK, 1-24.

7. Kabeer, N. (2001). Conflicts over credit: re-evaluating the empowerment potential of loans to women in rural Bangladesh. World Development, 29(1), 63-84.

8. Unnayan, O. (2014). State of Unemployment and Poverty. Bangladesh Economic Update, 5(5), 13-23.

9. Salway, S., Rahman, S., \& Jesmin, S. (2004). A profile of women's work participation among the urban poor of Dhaka, World Development, 31(5), 881-901.

10. Schregel, J. (1976). Workers' participation in decision making within undertakings. International Labour Review, 113(1), 1-24.

11. Rahman, R. I., \& Khandker, S. R. (1994). Role of targeted credit programs in promoting employment and productivity of the poor in Bangladesh. Bangladesh Journal of Development Studies, 22(2/3), 49-92.

12. Kabeer, N., \& Mahmud. S. (2004). Globalisation, gender and poverty: Bangladeshi women workers in export and local markets. Journal of International Development, 16, 93-109.

13. Kabeer, N. (2003). Mainstreaming Gender in Poverty Eradication and the Millennium Development Goals. Commonwealth Secretariat and IDRC: London and Ottawa, 3, 1-17.

14. Ahmed, N., \& Dev. N. (2014, May). Improving wages and working conditions in the Bangladeshi garment sector: the role of horizontal and vertical relations. Capturing the Gains, Working Paper, 40, 1-21.

15. Sohail, A., \& Alam, Q. (2016). How to develop a sustainable workplace and 5Es. Paper presented at a seminar titled 'Ethics, Efficiency and Productivity in the RMG sector: Towards $\$ 50$ billion Exports by 2021' jointly organized by University of Dhaka, Monash University, Australia \& University of Warwick, UK, 1-18.

16. Sinkovics, N., Hoque, S. F. \& Sinkovics, R. (2016). Rana Plaza collapse aftermath: is CSR compliance and auditing pressures effective? Accounting, Auditing \& Accountability Journal, 29(4), 617-649.

17. Chandran, R. (2016). Case 3: Three years after Rana Plaza disaster, has anything changed? Retrieved from: http:// www.reuters.com/article/us-bangladesh-garments-lessons-analysis-idUSKCN0XJ02G, 21. (date of access: 23 April, 2016).

18. Huda, M. N., Shamsur, A. \& Shahjada, A. M. (2016). The role of stakeholders in preventing irregularities and corruption prevailing in the supply chain of the RMG sector. Transparency International Bangladesh (TIB), 1-56. 
19. Saxena, S. B. (2010, July). Competitiveness in the Garment and Textiles Industry: Creating a supportive environment. A Case Study of Bangladesh, Occasional Paper No. 1. The Asia Foundation, 6-35.

20. Stiglitz, J. (2002, September). Developing policies in a world of globalization. Paper presented at the seminar "New International Trends for Economic Development" on the occasion of the fiftieth anniversary of the Brazilian Economic and Social Development Bank (BNDES), Rio Janeiro, 12-13, 1-25.

\section{Authors}

Muhammad Mahboob Ali - PhD in Economics, Professor, Daffodil International University; Former Vice Chancellor, Presidency University (Bangladesh, 1207, Dhanmondi 102, Shukrabad; Dhaka; e-mail: pipulbd@gmail.com).

Anita Medhekar - Master of Economics, PhD (Researcher), Senior Lecturer in Economics, School of Business and Law, Central Queensland University (Building 34/2.13, Off Bruce Highway, 4702, Rockhampton, 443256, Australia; e-mail: a.medhekar@cqu.edu.au). 